\title{
IONIC SPECIATION IN A DYSTROPHIC RED LATOSOL UNDER COFFEE CROP AND HIGH DOSES OF GYPSUM
}

\author{
Bárbara Zini Ramos ${ }^{1}$, José Maria de Lima², Milson Evaldo Serafim³ ${ }^{3}$ Aline Renée Coscione ${ }^{4}$, \\ Raul Magalhães Ferraz ${ }^{5}$, Lucas Mota Amorim6, Guilherme Lopes ${ }^{7}$
}

(Received: January 23, 2019; accepted: July 03, 2019)

\begin{abstract}
The cultivation of coffe crops in Brazil, especially on Latosols, has been increasing over the years, despite limitations such as aluminum toxicity, low fertility and very long drought periods. In this scenario, soil amendments to mitigate these restraints are necessary. Since these limitations are not restricted to the arable layer, application of gypsum becomes an efficient alternative to sustain soil fertility and deepen the root system to get water from the deeper layers of soil. However, high doses of gypsum can cause unbalance among $\mathrm{Ca}^{2+}, \mathrm{Mg}^{2+}$ and $\mathrm{K}^{+}$. The objective of this work was to evaluate these bases as well as their ionic pairs, and the presence of sulfate along the soil profile 16 months after the application of high gypsum doses in a Latosol under coffee crops. An inicial dose of gypsum was applied in the entire area, followed by four treatments, in triplicate and randomized blocks, set as follows: G0 - zero gypsum applied over the planting line after the initial soil preparation; G7- 7 $\mathrm{t} \mathrm{ha}^{-1}$ of gypsum in the planting line $\left(1.75 \mathrm{~kg} \mathrm{~m}^{-1}\right)$; G56 - $56 \mathrm{t} \mathrm{ha}^{-1}$ of gypsum in the planting line $\left(14 \mathrm{~kg} \mathrm{~m}^{-1}\right)$, all with brachiaria between the coffee planting lines; and CV7 - $7 \mathrm{t} \mathrm{ha}^{-1}$ of gypsum in the line and no brachiaria between the planting lines. The soil profile was sampled in layers up to $2.40 \mathrm{~m}$ depth and the soil solution was extracted by suctioning the sample-saturated paste. Following this extraction, the soil solution was analyzed by combustion for total carbon contents, ion chromatography and ICP-OES/flame photometry, for chemical species, and speciation was done using Minteq software. After 16 months of gypsum application, $96 \%$ of $\mathrm{K}^{+}$in soil solution was at 0.35 to $0.45 \mathrm{~m}$ in its free form. Leaching of $\mathrm{Ca}^{2+}$ and $\mathrm{Mg}^{2+}$ occurred predominantly in their free forms, although a more significant contribution of $\mathrm{CaSO}_{4}{ }^{0}$ and $\mathrm{MgSO}_{4}{ }^{0}$ ionic pairs was observed when compared to $\mathrm{K}_{2} \mathrm{SO}_{4}{ }^{0}$
\end{abstract}

Index terms: Nutrients leaching, oxisol, soil profile.

\section{ESPECIAÇÃO IÔNICA EM UM LATOSSOLO VERMELHO DISTRÓFICO CULTIVADO COM CAFÉ SOB ALTAS DOSES DE GESSO}

RESUMO: O cultivo de café no Brasil, especialmente em Latossolos, tem aumentado ao longo dos anos, apesar de algumas limitações, como a toxicidade do alumínio, baixa fertilidade e períodos de seca muito prolongada. Neste cenário, alterações no solo para mitigar essas limitações são necessárias. Como estas limitações não se limitam à camada arável, a aplicação de gesso torna-se uma alternativa eficiente para uma fertilidade sustentável do solo ao longo do perfil do solo e para aprofundar o sistema radicular, a fim de obter água das camadas mais profundas do solo. Entretanto, altas doses de gesso podem causar desequilíbrio entre $\mathrm{Ca}^{2+}, \mathrm{Mg}^{2+}$ e $\mathrm{K}^{+}$. O objetivo deste trabalho foi avaliar essas bases, assim como seus pares iônicos, e sulfato ao longo do perfil do solo, 16 meses após a aplicação de doses elevadas de gesso em um Latossolo sob cafeeiro. Os tratamentos foram quatro, além da dose inicial de gesso, aplicada em toda a área, durante o preparo do solo, com três repetições e em blocos casualizados, definidos da seguinte forma: G0 - zero de gesso após a primeira dose aplicada durante o preparo inicial do solo; G7- $7 \mathrm{t} \mathrm{ha}^{-1}$ de gesso na linha de plantio $\left(1,75 \mathrm{~kg} \mathrm{~m}^{-1}\right)$; G56 - $56 \mathrm{t} \mathrm{ha}^{-1}$ de gesso na linha de plantio $\left(14 \mathrm{~kg} \mathrm{~m}^{-1}\right)$, todos com braquiária entre as linhas de plantio de café; e CV7 - $7 \mathrm{t} \mathrm{ha} \mathrm{a}^{-1}$ de gesso na linha e sem braquiária entre as linhas de plantio. Amostramos o perfil do solo em camadas, até 2,4 m de profundidade, 16 meses após a aplicação do gesso, e extraímos a solução do solo por sucção da pasta saturada. Após a extração, a solução do solo foi analisada por combustão para determinação do teor total de carbono, cromatografia iônica e ICP-OES/fotometria de chama, e a especiação da solução foi feita usando o software Minteq. Após 16 meses da aplicação do gesso, $96 \%$ do $\mathrm{K}^{+}$da solução do solo na camada $0.35-0.45 \mathrm{~m}$ foi encontrado em sua forma livre. Para $\mathrm{Ca}^{2+}$ and $\mathrm{Mg}^{2+}$, a lixiviação também ocorreu predominantemente em suas formas livres, porém a contribuição dos pares iônicos $\mathrm{CaSO}_{4}{ }^{0}$ and $\mathrm{MgSO}_{4}{ }^{0}$ foi muito mais significativa comparativamente ao $\mathrm{K}_{2} \mathrm{SO}_{4}{ }^{\circ}$.

Termos para indexação: Lixiviação de nutrientes, solo oxídico, perfil do solo.

\section{INTRODUCTION}

Coffee crops are mainly planted between 700 and $1200 \mathrm{~m}$ of altitude and on topografic situations favorable to mechanization (Vale et al., 2014). The dominant soils in such conditions are Cambisols, Ultisols and Oxisols.The Oxisols (Latosols) have low fertility, with high aluminum

\footnotetext{
${ }^{1}$ In memoriam

${ }^{2,6}$ Centro de Ciências Agrárias, Ambientais e Biológicas/PPGSQE/UFRB - Tv. P. Brejinhos, 540 - 736 - $44.380-000$ - Cruz das Almas - BAjml.dcs@gmail.com, lucasmamorim@gmail.com

${ }^{3}$ Instituto Federal de Educação, Ciência e Tecnologia de Mato Grosso - Campus Cáceres - Avenida dos Ramires, s/n - Cx. P. 244 78.200-000 - Mato Grosso - MT milson.serafim@cas.ifmt.edu.br

${ }^{4}$ Instituto Agronômico - Avenida Barão de Itapura, no 1.481 - 13.020-902 - Campinas - SP - aline@iac.sp.gov.br

5,7Universaidade Federal de Lavras/UFLA - Departamento de Ciência do Solo/DCS - 37. 200-000 - Lavras - MG - raul.ferraz@ufla.br, guilherme.lopes@ufla.br
} 
and a low calcium contents below the plowing layer. These factors are adverse to coffee production, limiting root deepening, causing less water uptake, especially during the drought period, generalized nutrient deficiency, low organic matter content, and low cation exchange capacity (CEC). These factors are reinforced by the uneven distribution of rainfall during the year in these locations (Lopes \& Guilherme, 2016), resulting in low productivity and quality of the coffee product (Serafim et al., 2011).

To mitigate high aluminum and increase the low calcium content deeper in the soil profile, agricultural gypsum $\left(\mathrm{CaSO}_{4} \cdot 2 \mathrm{H}_{2} \mathrm{O}\right)$ has been used complementary to limestone (Bortolanza \& Klein 2016), reducing water stress and avoiding productivity losses through soil management practices (Silva et al, 2019). However, despite the many benefits of gypsum application to agricultural production, there are still many inconstancies concerning the amount of gypsum to be applied, which depends on the type of soil, rainfall index, and the cultivation system (Kost et al., 2014, Tiecher et al., 2018).

An intensive coffee cultivation system was developed in São Roque de Minas, Minas Gerais State, Brazil, denominated the AP Romero System (Serafim et al., 2011). It is characterized by the application of high doses of agricultural gypsum in an operation known as "white irrigation", in addition to soil fertilization and the cultivation of brachiaria between the lines of the coffee plants. Despite the positive results observed by the coffee producers of the region, as shown in Serafim et al. (2011), technical information is still lacking, especially about the chemical species in the soil profile and leaching of bases such as potassium and magnesium to layers beyond the root system.

In a previous study, Ramos et al. (2013) found a decrease in the contents of $\mathrm{K}^{+}$in the soil solution down to $0.85 \mathrm{~m}$. The authors verified that under the effect of gypsum ( 7 and 56 tha $\left.^{-1}\right) 16$ months after application, the content of exchangeable $\mathrm{K}^{+}$was close to the critical values needed for maintaining proper coffee crop nutrition.

Chemical speciation of soil solution is a valuable tool to understand the availability, movement, and form of nutrients along the soil profile, which cannot be accessed routinely by soil fertility laboratories. Such information can help producers to make decisions regarding the best dose and to understand plant's response to the adopted system (Zambrosi et al., 2007).
The objective in this work was to continue the previous work (Ramos et al., 2013), and assess the dynamics of the $\mathrm{Ca}^{2+}, \mathrm{Mg}^{2+}, \mathrm{K}^{+}$and $\mathrm{SO}_{4}^{2-}$ in the soil profile, by chemical speciation in the soil solution of a Red Latosol, under coffee crop which was planted with high doses of agricultural gypsum.

\section{MATERIAL AND METHODS}

The experimental area is located at Fazenda AP Família, which belongs to Agropecuária Piumhi LTDA, in São Roque de Minas, in the Physiographic Region of Upper São Francisco river basin, Center-West of the State of Minas Gerais, Brazil, in the latitude $20^{\circ} 14^{\prime} 42^{\prime \prime} \mathrm{S}$ and longitude $46^{\circ} 21^{\prime} 57^{\prime}$ 'W. The climate of the region is Cwa, according to the Köppen classification, with annual average rainfall of $1,344 \mathrm{~mm}$, with a dry season that extends from May to September. The annual average temperature is of $20.7^{\circ} \mathrm{C}$, with average relative humidity of $60 \%$, and an altitude of $900 \mathrm{~m}$ (Menegasse et al., 2002).

The soil is classified as a very clayey oxidic-gibbsitic mineralogy typic Dystrophic Red Latosol (Embrapa, 2018), which corresponds to an Anionic Acrustox (Soil Survey Staff, 1999). This is the most predominant soil in this region. Regarding particle size distribution, the soil has 763 and $819 \mathrm{~g} \mathrm{~kg}^{-1}$ of clay $(\varnothing<0.002 \mathrm{~mm}), 39$ and $33 \mathrm{~g} \mathrm{~kg}^{-1}$ of silt $(0.002-0.05 \mathrm{~mm})$, and 198 and $148 \mathrm{~g} \mathrm{~kg}^{-1}$ of sand $(0.05-2 \mathrm{~mm})$ in the Ap and Bw horizons, respectively. Amounts of $\mathrm{SiO}_{2}, \mathrm{Al}_{2} \mathrm{O}_{3} \mathrm{e}$ $\mathrm{Fe}_{2} \mathrm{O}_{3}$, as well as the weathering indexes ( $\mathrm{Ki} \mathrm{e} \mathrm{Kr}$ ) and fertility parameters of soil, with and without braquiaria in the inter-row of coffee plants, for depths up to $0.80 \mathrm{~m}$, are available in Ramos et al, 2013. Liming, gypsum, and fertilizer application, done during planting, formation, and coffee production are described in Serafim et al. (2011).

As used in a conventional tillage, the soil was limed and amended with gypsum ( $2 \mathrm{tha}^{-1}$, which was spread over the soil surface), as well as fertilization in furrows $50-\mathrm{cm}$ wide and $60-\mathrm{cm}$ deep, before planting the coffee (Coffea arabica L., Catucaí Amarelo Multilínea). This quantity of gypsum corresponded to $50 \%$ of the recommendation, based on the clay content of the soil, according to the soil analysis and considering the layer of 0.0-0.10 m. After this initial soil preparation, Urochloa ruziziensis was planted as a cover plant in the entire area before planting the lines of coffee plant (Serafim et al., 2011). 
Besides the inicial gypsum dose, which was applied in the entire area, four treatments, in triplicate and randomized blocks, were set as follows: G0 - zero gypsum applied after the application of after the application of gypsum during the initial soil preparation; G7- $7 \mathrm{t} \mathrm{ha}^{-1}$ of gypsum in the planting line $\left(1.75 \mathrm{~kg} \mathrm{~m}^{-1}\right)$; G56 $56 \mathrm{t} \mathrm{ha}^{-1}$ of gypsum in the planting line $\left(14 \mathrm{~kg} \mathrm{~m}^{-1}\right)$, with brachiaria between the coffee planting lines; and CV7 - $7 \mathrm{t} \mathrm{ha}^{-1}$ of gypsum in the line and no brachiaria between the planting lines (Figure 1). Sixteen months later, the soil profile in each treatment was sampled in the planting lines at the following depths: 0.15 to $0.25,0.35$ to 0.45 , 0.75 to 0.85 , and 2.35 to $2.45 \mathrm{~m}$ (Figure 1 - right), totalizing 96 samples. These samples were airdried, crushed, passed through a $2 \mathrm{~mm}$ mesh sieve, placed in plastic bags, and stored for the further analysis.

To extract the soil solution, we used the saturated soil-paste method (Wolt, 1994). To do this, ultrapure water was slowly added to $300 \mathrm{~g}$ of soil sample until reaching the saturation point. The sample rested for $16 \mathrm{~h}$ then was placed in a Büchner funnel, containing paper filter (rapid filtration) coupled to a Kitassato flask. The solution was extracted under vacuum for about $9 \mathrm{~h}$, and then filtered through $0.45 \mu \mathrm{m}$ cellulose membrane and stored for further analysis. The $\mathrm{pH}$ was determined directly in the extract. The dissolved organic carbon (DOC) was quantified (Varian, TOC analyzer) for total carbon content, by combustion at $950^{\circ} \mathrm{C}$. The contents of the $\mathrm{Ca}^{2+}, \mathrm{Mg}^{2+} \mathrm{Mn}^{2+}, \mathrm{Cu}^{2+}, \mathrm{Zn}^{2+}, \mathrm{Fe}^{3+}, \mathrm{Al}^{3+}$ in the soil solution were determined by plasma emission spectroscopy with optical detection (Varian, Vista MPX, axial view), while $\mathrm{K}^{+}$and $\mathrm{Na}^{+}$were determined by flame photometry (Micronal B462). Ion chromatography (Dionex, ICS 1100 with IONs OACK AS23 column for anions or Ion Pack CS12A for cations) was used to determine $\mathrm{F}^{-}, \mathrm{Cl}^{-}, \mathrm{NO}^{2-}, \mathrm{NO}^{3-} \mathrm{PO}_{4}^{2-}, \mathrm{SO}_{4}^{2-}$ and $\mathrm{NH}_{4}^{+}$. Results below the equipment's quantification limit were observed for $\mathrm{Cu}^{2+}, \mathrm{Zn}^{2+}, \mathrm{Fe}^{3+}, \mathrm{Al}^{3+}, \mathrm{PO}_{4}^{2-}$, corresponding to $0.06,0.03,0.35,0.07$, and 0.03 $\mathrm{mg} \mathrm{L}^{-1}$, respectively. Thus, these species were not considered neither for soil solution chemical speciation or the ionic strength calculations. The soil solution ionic strength $(\mu)$ was calculated according to Sposito (1989): $\mu=\frac{1}{2} \sum c_{i} z_{i}^{2}$

where $C i$ is concentration of ion $\left(\mathrm{mol} \mathrm{L}^{-1}\right)$ of each ion, and $Z i$ is the respective charge.

The soil solution chemical speciation was done using the Visual Minteq program (Gustaffson, 2018), based on the total concentrations $\left(\mathrm{mg} \mathrm{L}^{-1}\right)$ of all the cations, anions, DOC, and $\mathrm{pH}$ obtained as described above, for each treatment and soil depth sampled in the field. The results of soil chemical tests were submitted to analysis of variance. The experimental design was a randomized block design with three replications. The clustering of the means was done by the Scott-Knott test, adopting the $p$ values 0.05 as criterion of significance of the difference between the means. The data were processed using the software SISVAR 5.6, Build 86 (Ferreira, 2014).
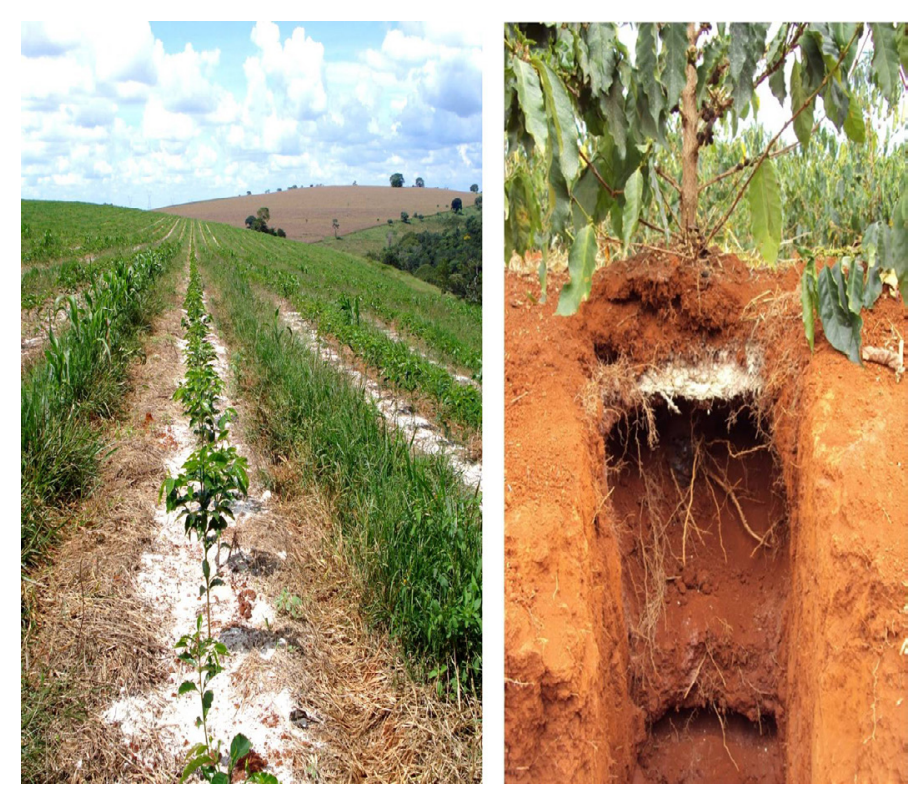

FIGURE 1 - Partial view of the experimental area (left) and detail of the sampling trench showing the gypsumburied layer of the $56 \mathrm{t} \mathrm{ha}^{-1}$ treatment (right). 


\section{RESULTS AND DISCUSSION}

Ionic strength $(\mu)$ of the soil solution of treatments is demonstrated in Figure 2. Ionic strength decreases with the increase in soil depth. Despite the higher solubility of gypsum, when compared to lime, 16 months of leaching wasn't enough to cause a significant increase of calcium and sulfate in the subsoil. Results reported by Ramos et al. (2013) indicated presence of $\mathrm{Ca}^{2+}$, $\mathrm{Mg}^{2+}$, and $\mathrm{K}^{+} 16$ months after the application of gypsum, only until $0.45-\mathrm{m}$ of depth. The results presented in Figure 2 for the treatments G7 and CV7 corroborate with the results obtained by Ramos et al. (2013). Furthermore, treatments G7 and G56 in the planting line differed only in the surface layer, indicating that, in addition to carrying ions, solubilization of gypsum and consequent leaching take longer than 16 months to produce some result deeper in the soil profile.

The increase in the concentration of electrolytes in the soil solution, indicated by the ionic strength, reduces the thickness of the diffuse electric-double layer, neutralizes negative surfaces, reduces $\mathrm{pH}$, increases mobility, and reduces adsorption of bases in the solid phase of the soil (Sposito, 1989). Therefore, $\mathrm{Ca}^{2+}, \mathrm{Mg}^{2+}$, and $\mathrm{K}^{+}$are subject to leaching to the subsurface layers of soil. The magnitude of this effect is a function of the dominant cation in the soil solution. In the present study, it is $\mathrm{Ca}^{2+}$, which is provided by the gypsum. We found higher amounts of $\mathrm{Ca}^{2+}$ in the soil solution (Table 3), followed by $\mathrm{Mg}^{2+}$ (Table 4), and $\mathrm{K}^{+}$(Table 5).

The free form of $\mathrm{SO}_{4}^{2-}$ was the most dominant chemical species in the soil solution, regardless of the treatment or sampled depth (Table 1), corroborating results found by Zambrosi et al. (2007) on a soybean nutrition experiment. The authors evaluated the distribution of ionic species in the soil solution of a Latosol cultivated in a no-tillage system (NTS), five years after the application of agricultural gypsum. The highest proportion ionic pairs was for $\mathrm{CaSO}_{4}{ }^{0}$, followed by $\mathrm{MgSO}_{4}{ }^{0}$, with the highest percentages present in the planting line at the depth of $0.85 \mathrm{~m}$, being higher for the higher doses of gypsum. In this case, up to $4 \%$ of sulfate was $\mathrm{MgSO}_{4}$, and up to $13.5 \% \mathrm{CaSO}_{4}$. Other ionic pairs $\mathrm{NaSO}_{4}^{-}, \mathrm{KSO}_{4}^{-}$, $\mathrm{HSO}_{4}^{-}, \mathrm{MnSO}_{4}^{0}, \mathrm{AlSO}_{4}^{+}, \mathrm{NH}_{4} \mathrm{SO}_{4}^{-}$) were found in the soil solution of samples from the planting line. These other species account for about $0.4 \%$ of the total (Table 1).

We verified an increase in the content of $\mathrm{SO}_{4}^{2-}$ at 0.15 to 0.25 and 0.35 to $0.45 \mathrm{~m}$ depth in the inter-row of $\mathrm{G} 7$ treatment, which is covered with Urochloa ruziziensis, as compared to treatment CV7, where the inter-row were left nude.

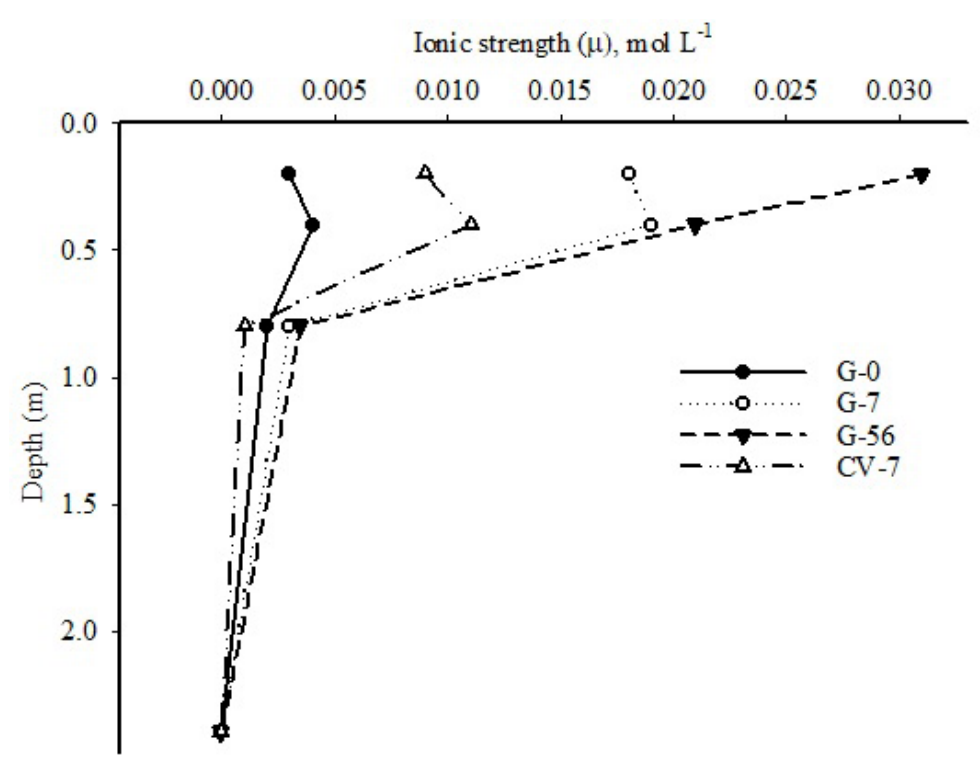

FIGURE 2 - Effect of gypsum on ionic strength $(\mu), \mathrm{mol} \mathrm{L}^{-1}$ of the solution of of Latosol under coffee crop and high doses of gypsym.

$\mathrm{G} 0$ - only the first applied gypsum during soil preparation; $\mathrm{G} 7-7 \mathrm{tha} \mathrm{h}^{-1}$ of gypsum in the planting line $\left(1.75 \mathrm{~kg} \mathrm{~m}^{-1}\right)$; G56 - $56 \mathrm{t} \mathrm{ha}^{-1}$ of gypsum in the planting line $\left(14 \mathrm{~kg} \mathrm{~m}^{-1}\right)$, all of them with brachiaria between the coffee plant lines; and CV7 $-7 \mathrm{tha}^{-1}$ of gypsum in the line and no brachiaria between the lines. 
TABLE 1 - Distribution of $\mathrm{SO}_{4}{ }^{2-}, \mathrm{MgSO}_{4}$ and $\mathrm{CaSO}_{4}$ in the solution of a Latossol planted with coffee with high doses of gypsum.

\begin{tabular}{|c|c|c|c|c|c|c|}
\hline \multirow{2}{*}{$\begin{array}{c}\text { Depth } \\
\text { (m) }\end{array}$} & \multirow[t]{2}{*}{ Treatments } & \multirow{2}{*}{$\begin{array}{c}\mathrm{SO}_{4}^{2-} \\
\mathrm{mg} \mathrm{dm}^{-3}\end{array}$} & $\mathrm{SO}_{4}{ }^{2-}$ & $\mathrm{MgSO}_{4}{ }^{0}$ & $\mathrm{CaSO}_{4}{ }^{0}$ & \multirow[t]{2}{*}{ Others $^{(1)}$} \\
\hline & & & & -Spec & $\%)$ & \\
\hline \multirow{4}{*}{$0.15-0.25$} & $\mathrm{G} 0^{2}$ & $14.8 \pm 21.7 \mathrm{c}$ & 86.2 & 5.3 & 8.4 & 0.1 \\
\hline & G7 & $676.0 \pm 9.2 \mathrm{a}$ & 62.1 & 6.3 & 31.4 & 0.2 \\
\hline & G56 & $1121.9 \pm 36.1 \mathrm{a}$ & 52.6 & 6.2 & 40.9 & 0.3 \\
\hline & CV7 & $259.5 \pm 25.6 \mathrm{~b}$ & 70.9 & 2.1 & 26.7 & 0.3 \\
\hline \multirow{4}{*}{$0.35-0.45$} & G0 & $14.2 \pm 27.2 \mathrm{c}$ & 90.3 & 5.3 & 4.1 & 0.3 \\
\hline & G7 & $700.3 \pm 13.0 \mathrm{a}$ & 59.5 & 6.9 & 33.3 & 0.3 \\
\hline & G56 & $636.0 \pm 14.9 \mathrm{a}$ & 58.4 & 11.3 & 29.9 & 0.4 \\
\hline & CV7 & $344.8 \pm 17.4 \mathrm{~b}$ & 67.9 & 7.4 & 24.5 & 0.2 \\
\hline \multirow{4}{*}{$0.75-0.85$} & G0 & $\mathrm{nd}^{*}$ & - & - & - & - \\
\hline & G7 & $0.22 \pm 3.4 \mathrm{~b}$ & 87.6 & 5.2 & 6.5 & 0.7 \\
\hline & G56 & $0.23 \pm 7.5 \mathrm{~b}$ & 88.5 & 2.7 & 8.4 & 0.4 \\
\hline & $\mathrm{CV} 7$ & $0.53 \pm 20.0 \mathrm{a}$ & 97.7 & 0.8 & 1.2 & 0.3 \\
\hline \multirow{5}{*}{$2.35-2.45$} & G0 & nd $^{*}$ & - & - & - & - \\
\hline & G7 & $\mathrm{nd}^{*}$ & - & - & - & - \\
\hline & G56 & $\mathrm{nd}^{*}$ & - & - & - & - \\
\hline & CV7 & $\mathrm{nd}^{*}$ & - & - & - & - \\
\hline & Mean values & & 51.4 & 3.7 & 13.5 & 0.22 \\
\hline
\end{tabular}

Means followed by the same letter in the column do not differ between each other by the ScottKnot test $(\mathrm{p} \leq 0.05)$.

(1) Other species of sulfate: $\mathrm{NaSO}_{4}^{-}, \mathrm{KSO}_{4}^{-}, \mathrm{HSO}_{4}^{-}, \mathrm{MnSO}_{4}{ }^{0}, \mathrm{AlSO}_{4}{ }^{+}, \mathrm{NH}_{4} \mathrm{SO}_{4}^{-}$.

(2) $\mathrm{G} 0$ - only the first applied gypsum during soil preparation; G7- $7 \mathrm{t} \mathrm{ha}^{-1}$ of gypsum in the planting line $\left(1.75 \mathrm{~kg} \mathrm{~m}^{-1}\right)$; G56 - $56 \mathrm{t} \mathrm{ha}^{-1}$ of gypsum in the planting line $\left(14 \mathrm{~kg} \mathrm{~m}^{-1}\right)$, all of them with brachiaria between the coffee plant lines; and CV7 - $7 \mathrm{tha}^{-1}$ of gypsum in the line and no brachiaria between the lines.

*nd: not detected.

Gypsum percolation to the depth $0.35-0.45 \mathrm{~m}$ increased $\mathrm{SO}_{4}^{2-}$ and $\mathrm{Ca}^{2+}$ (Table, 1), allowing bether growth of root system. It resulted in higher DOC (Table 2), due to the growth of Urochloa ruziziensis root system. In the same area, Serafim et al. (2011) also found that the roots of the coffee plants reached an average depth of $1.40 \mathrm{~m}$. Ramos et al. (2013) reported higher amounts of $\mathrm{Ca}^{2+}$ and $\mathrm{Mg}^{2+}$ in treatments $\mathrm{G} 7$ and G56, compared to G0 and CV7, at 0.35- to 0.45-m depth.

The contents of $\mathrm{Ca}^{2+}$ (Table 3) showed significant differences at $0.15-0.25 \mathrm{~m}$ depth, indicating differences between treatments with gypsum only among the preparation (G0) and the treatments G7 and G56. Increasing dose of gypsum, caused an increase of $\mathrm{Ca}^{2+}$ contents in the soil solution until the depth from 0.75 to 0.85 $\mathrm{m}$. This was accounted for by leaching of $\mathrm{Ca}^{2+}$ to deeper layers of the soil where higher gypsum was applied. Regarding the cultivation of Urochloa ruziziensis, there was difference between the treatment G7 and CV7 only in the layer from 0.75 to $0.85 \mathrm{~m}$. Serafim et al. (2012), Crusciol et al. (2016), Inagaki et al. (2016), and Zoca \& Penn (2017) also found similar results, demonstrating that the application of gypsum caused an increase in the levels of $\mathrm{Ca}^{2+}$ in the subsurface layers of the soil, and indicating the carriage of this nutrient to the layers beyond the depth of application. We observed no differences in the contents of $\mathrm{Ca}^{2+}$ and $\mathrm{SO}_{4}^{2-}$ between treatments $\mathrm{G} 7$ and G56 at depths from 0.35 to 0.45 and 0.75 to $0.85 \mathrm{~m}$ (Table 3). 
TABLE 2 - Mean contents of DOC in the solution of a Latossol planted with coffee with high doses of gypsum.

\begin{tabular}{ccc}
\hline Depth & \multicolumn{2}{c}{ DOC $\left(\mathrm{mg} \mathrm{L}^{-1}\right)$} \\
\cline { 2 - 3 }$(\mathrm{m})$ & $\mathrm{G}^{(1)}$ & $\mathrm{CV7}$ \\
\hline $0.15-0.25$ & $165 \pm 1.1 \mathrm{a}$ & $140 \pm 1.2 \mathrm{~b}$ \\
$0.35-0.45$ & $118 \pm 4.1 \mathrm{a}$ & $87 \pm 12.3 \mathrm{~b}$ \\
$0.75-0.85$ & $84 \pm 10.7 \mathrm{a}$ & $80 \pm 15.6 \mathrm{a}$ \\
$2.35-2.45$ & $26 \pm 9.6 \mathrm{~b}$ & $40 \pm 1.2 \mathrm{a}$
\end{tabular}

Means followed by the same letter in the line do not differ between each other by the ScottKnot test $(\mathrm{p} \leq 0.05)$.

${ }^{(1)} \mathrm{G} 7$ - gypsum in the preparation and $7.0 \mathrm{t} \mathrm{ha}^{-1}$ of gypsum in the planting line; CV7- absence of gypsum in the preparation, $7 \mathrm{tha}^{-1}$ of gypsum in the line.

TABLE 3 - Mean contents of $\mathrm{Ca}^{2+}$ and respective chemical species in the soil solution of a Latossol planted with coffee with high doses of gypsum.

\begin{tabular}{|c|c|c|c|c|c|c|}
\hline \multirow{2}{*}{$\begin{array}{l}\text { Depth } \\
\text { (m) }\end{array}$} & \multirow[t]{2}{*}{ Treatments } & \multirow{2}{*}{$\begin{array}{c}\mathrm{Ca}^{2+} \\
\mathrm{mg} \mathrm{dm}{ }^{-3}\end{array}$} & $\mathrm{Ca}^{2+}$ & $\mathrm{CaSO}_{4}{ }^{0}$ & Ca-DOC & Others $^{(1)}$ \\
\hline & & & \multicolumn{4}{|c|}{$\longrightarrow$ Species $(\%)$} \\
\hline \multirow{4}{*}{$0.15-0.25$} & $\mathrm{G}^{(2)}$ & $32.1 \pm 20.1 \mathrm{c}$ & 78.9 & 1.2 & 19.8 & 0.1 \\
\hline & G7 & $261 \pm 29.6 b$ & 62.1 & 33.9 & 3.8 & 0.2 \\
\hline & G56 & $446 \pm 32.0 \mathrm{a}$ & 52.9 & 42.8 & 3.5 & 0.8 \\
\hline & CV7 & $160 \pm 10.5 b$ & 73.6 & 18.0 & 8.3 & 0.1 \\
\hline \multirow{4}{*}{$0.35-0.45$} & G0 & $16.0 \pm 14.5 b$ & 79.1 & 1.6 & 18.9 & 0.4 \\
\hline & G7 & $287 \pm 20.8 \mathrm{a}$ & 62.4 & 33.9 & 3.5 & 0.2 \\
\hline & G56 & $253 \pm 39.1 \mathrm{a}$ & 64.7 & 31.4 & 3.6 & 0.3 \\
\hline & CV7 & $160 \pm 5.7 \mathrm{a}$ & 71.6 & 21.9 & 6.3 & 0.2 \\
\hline \multirow{4}{*}{$0.75-0.85$} & G0 & $14.0 \pm 14.0 \mathrm{~b}$ & 83.6 & - & 16.1 & 0.3 \\
\hline & G7 & $27.5 \pm 27.3 \mathrm{a}$ & 92.5 & 0.1 & 7.2 & 0.2 \\
\hline & G56 & $28.0 \pm 16.7 \mathrm{a}$ & 91.8 & 0.03 & 7.8 & 0.4 \\
\hline & CV7 & $19.0 \pm 18.7 \mathrm{c}$ & 58.1 & 0.04 & 41.8 & 0.06 \\
\hline \multirow{5}{*}{$2.35-2.45$} & G0 & nd" $^{*}$ & - & - & - & - \\
\hline & $\mathrm{G} 7$ & $\mathrm{nd}^{*}$ & - & - & - & - \\
\hline & G56 & $\mathrm{nd}^{*}$ & - & - & - & - \\
\hline & CV7 & $\mathrm{nd}^{*}$ & - & - & - & - \\
\hline & Mean values & & 54.5 & 11.6 & 8.8 & 0.20 \\
\hline
\end{tabular}

Means followed by the same letter in the column do not differ between each other by the ScottKnot test $(\mathrm{p} \leq 0.05)$.

${ }^{(1)}$ Other species of calcium: $\mathrm{CaCl}^{+}, \mathrm{CaHCO}_{3}{ }^{+}, \mathrm{CaNO}_{3}{ }^{+}, \mathrm{CaF}^{+}, \mathrm{CaH}_{2} \mathrm{PO}_{4}^{+}, \mathrm{CaHPO}_{4}$

(2) G0 - only the first applied gypsum during soil preparation; G7- $7 \mathrm{t} \mathrm{ha}^{-1}$ of gypsum in the planting line $\left(1.75 \mathrm{~kg} \mathrm{~m}^{-1}\right)$; G56 - $56 \mathrm{t} \mathrm{ha}^{-1}$ of gypsum in the planting line $\left(14 \mathrm{~kg} \mathrm{~m}^{-1}\right)$, all of them with brachiaria between the coffee plant lines; and CV7 - $7 \mathrm{t} \mathrm{ha}^{-1}$ of gypsum in the line and no brachiaria between the lines.

*nd: not detected. 
Lack of significant differences in this case means that the period of 16 months (basically one rainy season) was not a enough time to allow increasing leaching even with such a huge difference between gypsum doses. Further evaluations will certainly show differences.

The free form of $\mathrm{Ca}^{2+}$ was the main chemical species in the soil solution, regardless of the treatment and depth from which the samples were collected with an average proportion of $54.5 \%$ (Table 3). Zambrosi et al. (2007) also found the free form of $\mathrm{Ca}^{2+}$ represented $54 \%$. Marques et al. (2011) also found that the effect of gypsum on the content of water-soluble nutrients increased the content of $\mathrm{Ca}^{2+}$ in the soil at the $0-0.20 \mathrm{~m}$ layer, when compared to the treatment without gypsum. The ionic pair $\mathrm{CaSO}_{4}{ }^{0}$ represented $11.6 \%$ of the species in the planting lines (Table, 3). However, considering the total added gypsum to de soil, summing all the calcium species showed in the speciation calculation that less than $1 \%$ of added $\mathrm{Ca}^{2+}$ was found in the soil solution. The highest percentages of $\mathrm{CaSO}_{4}{ }^{0}$ were found in the treatments with the highest doses of gypsum (7 and $56 \mathrm{t} \mathrm{ha}^{-1}$ ), reaching $0.45 \mathrm{~m}$ in the soil profile. This shows that, although the formation of the iron pair occurs and is carried to the layer beyond the application, 16 months was not enough a time to allow losses of these cations layers beyond the depth of the roots. Leaching of $\mathrm{CaSO}_{4}{ }^{0}$ is of paramount importance to carry calcium and improve the root environment deeper in the soil profile (Zandoná, 2015; Zoca \& Penn ,2017).

From 0.15 to $0.85 \mathrm{~m}$, the ionic pair with DOC in the treatments with gypsum, only in the preparation (G0) represented $18.3 \%$ in the soil solution. The treatments G7 and G56 (7 and $\left.56 \mathrm{t} \mathrm{ha}^{-1}\right)$ represented less than 5\% (Table, 3 ).

Initially, $\mathrm{Ca}^{2+}$ is carried by DOC. Later, with the presence of gypsum, $\mathrm{CaSO}_{4}{ }^{0}$ becomes more important for carrying $\mathrm{Ca}^{2+}$ to the deeper layers of soil profile. We also observed that to the 0.45 $\mathrm{m}$ depth, higher doses of gypsum promoted an increase in the content of $\mathrm{Mg}^{2+}$ in the soil solution (Table 4).

TABLE 4 - Mean contents of $\mathrm{Mg}^{2+}$ and respective chemical species in the solution of a

Latossol planted with coffee with high doses of gypsum.

\begin{tabular}{|c|c|c|c|c|c|c|}
\hline \multirow{2}{*}{$\begin{array}{l}\text { Depth } \\
\text { (m) }\end{array}$} & \multirow[t]{2}{*}{ Treatment } & \multirow{2}{*}{$\begin{array}{c}\mathrm{Mg}^{2+} \\
\mathrm{mg} \mathrm{dm}\end{array}$} & $\mathrm{Mg}^{2+}$ & $\mathrm{MgSO}_{4}{ }^{0}$ & Mg-DOC & \multirow[t]{2}{*}{ Others $^{(1)}$} \\
\hline & & & - & $-\mathrm{S}$ & es $(\%)$ & \\
\hline \multirow{4}{*}{$0.15-0.25$} & $\mathrm{G}^{(2)}$ & $15.8 \pm 4.7 \mathrm{c}$ & 81.3 & 1.0 & 17.6 & 0.1 \\
\hline & G7 & $37.7 \pm 2.9 b$ & 66.8 & 28.9 & 3.5 & 0.8 \\
\hline & G56 & $47.4 \pm 5.6 \mathrm{a}$ & 58.5 & 37.6 & 3.3 & 0.6 \\
\hline & CV7 & $23.1 \pm 22.2 \mathrm{c}$ & 77.3 & 14.9 & 7.4 & 0.4 \\
\hline \multirow{4}{*}{$0.35-0.45$} & G0 & $24.5 \pm 20.7 \mathrm{~d}$ & 81.1 & 1.3 & 17.0 & 0.6 \\
\hline & G7 & $48.6 \pm 10.6 b$ & 67.5 & 29.1 & 3.3 & 0.1 \\
\hline & G56 & $68.1 \pm 0.87 \mathrm{a}$ & 69.4 & 26.8 & 3.3 & 0.5 \\
\hline & $\mathrm{CV} 7$ & $36.5 \pm 13.1 \mathrm{c}$ & 75.7 & 18.4 & 5.7 & 0.2 \\
\hline \multirow{4}{*}{$0.75-0.85$} & G0 & $36.4 \pm 26.3 \mathrm{a}$ & 85.1 & - & 14.5 & 0.4 \\
\hline & G7 & $13.3 \pm 12.6 \mathrm{a}$ & 92.9 & 0.07 & 6.7 & 0.3 \\
\hline & G56 & $19.7 \pm 13.7 \mathrm{a}$ & 92.8 & 0.02 & 7.0 & 0.2 \\
\hline & CV7 & $12.1 \pm 8.2 \mathrm{a}$ & 59.9 & 0.04 & 40.0 & 0.06 \\
\hline \multirow{5}{*}{$2.35-2.45$} & G0 & $18.3 \pm 16.4 b$ & 3.4 & - & 96.5 & 0.1 \\
\hline & G7 & $16.1 \pm 15.6 \mathrm{a}$ & 1.6 & - & 98.4 & - \\
\hline & G56 & $25.8 \pm 24.9 \mathrm{a}$ & 4.6 & - & 95.4 & - \\
\hline & $\mathrm{CV} 7$ & $35.4 \pm 33.5 \mathrm{~b}$ & 1.4 & - & 98.6 & - \\
\hline & Mean values & & 57.5 & 9.9 & 32.4 & 0.27 \\
\hline
\end{tabular}

Means followed by the same letter in the column do not differ between each other by the ScottKnot test $(\mathrm{p} \leq 0.05)$.

${ }^{(1)}$ Other species of magnesium: $\mathrm{MgCl}^{+}, \mathrm{MgHCO}_{3}{ }^{+}, \mathrm{MgF}^{+}, \mathrm{MgHPO}_{4}$.

(2) G0 - only the first applied gypsum during soil preparation; G7- $7 \mathrm{tha}^{-1}$ of gypsum in the planting line $\left(1.75 \mathrm{~kg} \mathrm{~m}^{-1}\right)$; G56 - $56 \mathrm{t} \mathrm{ha}^{-1}$ of gypsum in the planting line $\left(14 \mathrm{~kg} \mathrm{~m}^{-1}\right)$, all of them with brachiaria between the coffee plant lines; and CV7 - $7 \mathrm{tha}^{-1}$ of gypsum in the line and no brachiaria between the lines.

*nd: not detected. 
Rampim et al. (2011) also observed that, when using up to $5 \mathrm{tha}^{-1}$ of gypsum, $\mathrm{Mg}^{2+}$ leached to $0.40-\mathrm{m}$ depth, one year after application. Serafim et al. (2012), who studied the application of 6 doses of gypsum $\left(0,3,6,9,12\right.$, and $\left.15 \mathrm{tha}^{-1}\right)$ in a dystroferric Red Latosol, observed that the increase in the doses of gypsum resulted in leaching of $\mathrm{Mg}^{2+}$ from the plowing layer.

Among the inorganic anions, $\mathrm{SO}_{4}{ }^{2-}$ bonded mostly to $\mathrm{Mg}^{2+}, 9.9 \%$. This ion pair was observed, although in smaller percentages, until 0.85-m depth (Table, 4). These results corroborate the findings of Zambrosi et al. (2007), who also observed that $\mathrm{Mg}^{2+}$ was mostly associated with $\mathrm{SO}_{4}^{2-}(0.6 \%)$ when compared to $\mathrm{Cl}^{-}, \mathrm{NO}^{3-}, \mathrm{F}^{-}(0,1 \%)$ at $0.40 \mathrm{~m}$ of depth. According to Nava et al. (2012), the rate of movement of $\mathrm{Mg}^{2+}$ in the profile depends on the existence of other anions in the soil solution, especially nitrates and chlorides, derived mainly from the mineralization of $\mathrm{OM}$, or, in the case of sulfates, from the application of agricultural gypsum, which was the case of the present study. Caires et al. (2003) observed that, after 30 months of applying gypsum, the concentration of $\mathrm{Mg}^{2+}$ increased in the subsoil layers and, after 32 months, the gypsum continued to promote $\mathrm{Mg}^{2+}$ leaching to greater depths.

Contents of $\mathrm{K}^{+}$in the soil solution ranged from 0.001 to $0.014 \mathrm{cmol}_{\mathrm{c}} \mathrm{dm}^{-3}$ (Table 5). No influence of Urochloa ruziziensis cultivation was found in any of the evaluated depths. The content of $\mathrm{K}^{+}$in the soil solution between 0.003 (Malavolta, 2006) and $0.01 \mathrm{cmol}_{\mathrm{c}} \mathrm{dm}^{-3}$ (Guimarães et al., 1999) has indicated as a critical value for crop development. We found the highest values at $0.45 \mathrm{~m}$ depth in the planting line, providing $\mathrm{K}^{+}$ at greater depths, which is beneficial for plant absorption (Crusciol et al., 2016).

TABLE 5 - Mean contents of $\mathrm{K}^{+}$and respective chemical species in the solution of a Latossol planted with coffee with high doses of gypsum.

\begin{tabular}{|c|c|c|c|c|c|c|}
\hline \multirow{2}{*}{$\begin{array}{l}\text { Depth } \\
\text { (m) }\end{array}$} & \multirow[t]{2}{*}{ Treatment } & \multirow{2}{*}{$\begin{array}{l}\mathrm{K}^{+} \\
\mathrm{mg} \mathrm{dm}{ }^{-3}\end{array}$} & $\mathrm{~K}^{+}$ & $\mathrm{KSO}_{4}{ }^{0}$ & K-COD & Others $^{(1)}$ \\
\hline & & & \multicolumn{4}{|c|}{$\begin{array}{l}\text { Species }(\%) \\
\end{array}$} \\
\hline \multirow{4}{*}{$0.15-0.25$} & $\mathrm{G} 0^{2}$ & $2.8 \pm 0.5 \mathrm{~b}$ & 99.4 & 0.06 & 0.56 & 0.01 \\
\hline & G7 & $5.5 \pm 0.7 \mathrm{a}$ & 97.5 & 2.20 & 0.27 & 0.03 \\
\hline & G56 & $5.6 \pm 2.0 \mathrm{a}$ & 96.3 & 3.20 & 0.27 & 0.23 \\
\hline & CV7 & $5.4 \pm 1.1 \mathrm{a}$ & 98.6 & 1.00 & 0.39 & 0.01 \\
\hline \multirow{4}{*}{$0.35-0.45$} & G0 & $1.9 \pm 0.3 \mathrm{~b}$ & 99.3 & 0.08 & 0.55 & 0.07 \\
\hline & G7 & $4.9 \pm 2.5 \mathrm{a}$ & 97.5 & 2.20 & 0.25 & 0.05 \\
\hline & G56 & $3.6 \pm 1.1 \mathrm{a}$ & 97.7 & 2.00 & 0.24 & 0.06 \\
\hline & CV7 & $3.3 \pm 0.3 \mathrm{a}$ & 98.4 & 1.30 & 0.33 & - \\
\hline \multirow{4}{*}{$0.75-0.85$} & G0 & $4.0 \pm 0.4 \mathrm{a}$ & 99.5 & - & 0.42 & 0.08 \\
\hline & G7 & $4.4 \pm 0.2 \mathrm{a}$ & 99.6 & - & 0.31 & 0.09 \\
\hline & G56 & $3.9 \pm 2.1 \mathrm{a}$ & 99.6 & - & 0.26 & 0.14 \\
\hline & $\mathrm{CV} 7$ & $4.2 \pm 0.5 \mathrm{a}$ & 98.9 & - & 1.11 & 0.01 \\
\hline \multirow{5}{*}{$2.35-2.45$} & G0 & $0.6 \pm 0.09 \mathrm{a}$ & 97.8 & - & 2.20 & - \\
\hline & G7 & $0.9 \pm 0.5 \mathrm{a}$ & 95.1 & - & 4.90 & - \\
\hline & G56 & $0.7 \pm 0.2 \mathrm{a}$ & 97.6 & - & 2.40 & - \\
\hline & $\mathrm{CV} 7$ & $0.5 \pm 0.2 \mathrm{a}$ & 96.8 & - & 3.20 & - \\
\hline & Mean values & & 98.1 & 1.51 & 1.10 & 0.07 \\
\hline
\end{tabular}

Means followed by the same letter in the column do not differ between each other by the ScottKnot test $(\mathrm{p} \leq 0.05)$.

(1) Other species of potassium: $\mathrm{KCl}, \mathrm{KNO}_{3}$.

(2) G0 - only the first applied gypsum during soil preparation; G7- $7 \mathrm{t} \mathrm{ha}^{-1}$ of gypsum in the planting line $\left(1.75 \mathrm{~kg} \mathrm{~m}^{-1}\right)$; G56 - $56 \mathrm{t} \mathrm{ha}^{-1}$ of gypsum in the planting line $\left(14 \mathrm{~kg} \mathrm{~m}^{-1}\right)$, all of them with brachiaria between the coffee plant lines; and CV7 - $7 \mathrm{tha}^{-1}$ of gypsum in the line and no brachiaria between the lines. 
There was more $\mathrm{K}^{+}$in the soil solution in the treatments with gypsum than found in treatment $\mathrm{G} 0$ at depth of $0.45 \mathrm{~m}$. This is due, primary, to the $\mathrm{K}$ input by the mineral fertilization of soil for coffee planting. Potassium was predominantly found in its free form. Considering the electrolytes and the diffuse electric-double layer scenario, leaching of $\mathrm{K}^{+}$was caused by the dominant presence of $\mathrm{Ca}^{2+}$ over the diffuse double layer. Deeper in the soil profile, we verified that there was no difference between the content of $\mathrm{K}^{+}$between treatment $\mathrm{G} 0$ and those with higher doses of gypsum. Leaching of $\mathrm{K}^{+}$can be attributed to the gypsum "pulse" (Quaggio, et al., 1982). Potassium leaching is promoted by the high electrolytes concentration, reflected by the high ionic strength of the soil solution and the consequent reduced thickness of the electric-double layer with dominance of $\mathrm{Ca} 2+$ on the diffuse double layer.

As a monovalent cation, $\mathrm{K}^{+}$is more leachable in soil when compared to $\mathrm{Ca}^{2+}$ and $\mathrm{Mg}^{2+}$. On the other hand, $\mathrm{Ca}^{2+}$, with lower hydration radii than $\mathrm{Mg}^{2+}$ is more adsorbed to the soil colloids, and is strongly retained in the soil when compared to $\mathrm{Mg}^{2+}$ and $\mathrm{K}^{+}$.

\section{CONCLUSIONS}

After 16 months of gypsum application, $96 \%$ of $\mathrm{K}^{+}$in soil solution was at 0.35 to $0.45 \mathrm{~m}$ in its free form, besides de presence of the ionic pairs $\mathrm{KSO}_{4}{ }^{0}$ e K-COD. K-COD was related to the bracharia planted in the inter rows of coffee plants For $\mathrm{Ca}^{2+}$ and $\mathrm{Mg}^{2+}$ leaching occurred predominantly in its free forms, although a more significant contribution of $\mathrm{CaSO}_{4}{ }^{0}$ and $\mathrm{MgSO}_{4}{ }^{0}$ ionic pairs was observed when compared to $\mathrm{K}_{2} \mathrm{SO}_{4}^{0}$.

The use of high doses of gypsum in the soil requires long-term monitoring to better evaluate the feasibility of this practice in terms of chemical changes throughout the soil profile, mainly to further leaching of $\mathrm{K}^{+}$and $\mathrm{Mg}^{2+}$, which are already found in lower concentrations in the soil.

\section{ACKNOWLEDGMENTS}

The authors would like to express their appreciation to Fapemig and CNPq for the financial support and scholarships, to Agropecuaria Piumhi - AP, for allowing this research in its Commercial Coffee farm and providing all the necessary field support, and to Soil Science Department - UFLA for all the necessary laboratorial support.

\section{REFERENCES}

Bortolanza, D.R., Klein V.A. Soil Chemical and Physical Properties on an Inceptisol after Liming (Surface and Incorporated) Associated with Gypsum Application. Revista Brasileira de Ciência do Solo, Viçosa, Brazil, v.40: e0150377, 2016.

Caires, E.F.; Blum, J.; Barth, G.; Garbuio, F.J.; Kusamn M.T. Alterações químicas do solo e resposta da soja ao calcário e gesso aplicados na implantação do sistema plantio direto. Revista Brasileira de Ciência do Solo, Viçosa, Brazil. v. 27, p. 275-286., 2003. doi.: 10.1590/ S0100-06832003000200008

Crusciol, C.A.C., Artigiani, A.C.C.A., Arf, O., Filho, A.C.A.C., Soratto, R.P., Nascente, A.S., Alvarez, R.C.F., Soil fertility, plant nutrition, and grain yield of upland rice affected by surface application of lime, silicate, and phosphogypsum in a tropical notill system. Catena, v. 137, p.87-99, 2016.

EMPRESA BRASILEIRA DE PESQUISA AGROPECUÁRIA - EMBRAPA. Sistema brasileiro de classificação de solos. 5.ed. Brasília, Embrapa; 2018.

Ferreira, D.F. 2014. Sisvar: A Guide for its bootstrap procedures in multiple comparisons. Ciência e Agrotecnolgia, Lavras, v.38, n. 2, p.109-112, mar./abr., 2014. doi.: 10.1590/S1413-70542014000200001

Guimarães, P.T.G.; Garcia, A.W.R.; Alavarez Viegas, V.H.; Prezotti, L.C.; Viana, A.S.; Miguel, A.E.; Malavolta, E.; Correa J.B.; Lopes, A.S.; Nogueira, F.D.; Monteiro, A.V.C. Cafeeiro. In: Ribeiro, A.C.; Guimarães P.T.G.; Alvarez Viegas V.H. (Ed.). Recomendações para o uso de corretivos e fertilizantes em Minas Gerais: 5a aproximação. Viçosa, MG: Comissão de Fertilidade do Solo do Estado de Minas Gerais, 1999.

Gustaffson, J. P. Visual Minteq - version 3.0 beta; Acesso em 17/12/2018. Disponível em: < https:// vminteq.lwr.kth.se/>.

Inagaki MT, Sá JC de M, Caires EF, Gonçalves DRP. Lime and gypsum application increases biological activity, carbono pools, and agronomic productivity in highly weathered soil. Agriculture, Ecosystems and Environment, v. 231, p.156-165, 2016.

Kost, D., Chen, L., Guo, X., Tian, Y., Ladwig, K., Dick, W.A.,. Effects of flue gas desulfurization and mined gypsums on soil properties and on hay and corn growth in eastern Ohio. J. Environ. Qual., v.43, p. 312-321, 2014. 
Lopes AS; Guilherme LRG. Career Perspective on Soil Management in the Cerrado Region of Brazil. Advances in Agronomy, v.35, p. 1-72, 2016. doi: 10.1016/bs.agron.2015.12.004,

Malavolta, E. Manual de nutrição mineral de plantas. 1 ed. São Paulo, Agronômica Ceres, 2006.

Marques, R.R.; Crusciol, C.A.C.; Castro, G.S.A.; Perim, L. Water-soluble nutrients in aerial plant parts of peanut and white oat as affected by lime and gypsum application. Revista Brasileira de Ciência do Solo, Viçosa, Brasil, v. 35. p.513-522, 2011. doi: 10.1590/ S0100-06832011000200020.

Menegasse, L.N.; Gonçalves, J.M.; Fantinel, L.M. Disponibilidades hídricas na Província Cárstica de Arcos-Pains-Doresópolis, Alto São Francisco, Minas Gerais. Aguas Subterraneas v.16, p. 1-19, 2002. doi. 10.14295/ras.v16i1.1297

Nava, G.; Ernani, P.R.; Sá, A.A.; Pereira, A.J. Soil Composition and nutritional status of apple as affected by long-term application of gypsum. Revista Brasileira de Ciência do Solo, Viçosa, Brazil, v. 36, p.215-222, 2012.

Quaggio, J.A.; Dechen, A.R.; Raij, B. van. Efeitos da aplicação de calcário e gesso sobre a produção de amendoim e lixiviação de bases no solo. Revista Brasileira de Ciência do Solo, Viçosa, Brazil, v. 6, p.189-194, 1982.

Ramos, B.Z.; Toledo, J. P. V. F.; Lima, J.M.; Serafim, M. E.; Bastos, A. R. R.; Guimaraes, P.T.G.; Coscione, A.R. Doses de gesso em cafeeiro: influência nos teores de cálcio, magnésio, potássio e $\mathrm{pH}$ da solução de um Latossolo Vermelho distrófico. Revista Brasileira de Ciência do Solo, Viçosa, Brasil, v.37, p. 1018-1026, 2013. .doi: 10.1590/S0100-06832013000400019.

Rampim L.; Lana, M.C.; Frandioloso, J.F.; Fontaniva S. Atributos químicos de solo e resposta do trigo e da soja ao gesso em sistema semeadura direta. Revista Brasileira de Ciência do Solo, Viçosa, Brasil, v. 35, p.1687-1698, 2011 doi: 10.1590/S010006832011000500023.

Serafim M.E.; Oliveira, G.C.; Oliveira, A.S.; Lima, J.M.; Guimarães, P.T.G.; Costa, J.C. Sistema conservacionista e de manejo intensivo do solo no cultivo de cafeeiros na região do, MG: Um estudo de caso. Bioscience Journal, v. 27, p. 964-977, 2011.

Serafim, M.E.; Lima, J.M.; Lima, V.M.P.; Zeviani, W.M.; Pessoni P.T. Alterações físico-químicas e movimentação de íons em Latossolo gibbsítico sob doses de gesso. Bragantia, v. 71: p. 30-40, 2012. doi: 10.1590/S0006-87052012005000006

Silva, B. M. ., Oliveira, G. C. ., Serafin, M. E. ., Silva, E. A.a S., Guimaraes, P. T. G. ., Melo, L. B. B. ., Norton, L. D. ., Curi, N. C.. Soil moisture associated with least limiting water range, leaf water potential, initial growth and yield of coffee as affected by soil management system. Soil \& Tillage Research, v. 189, p. 36-43, 2019 DOI: $10.1016 /$ j.still.2018.12.016

Soil Survey Staff. Soil Taxonomy,. A Basic System of Soil Classification for Making and Interpreting Soil Surveys, second. ed. USDA Soil Conservation Service, US Gov. Printing Office, Washington - DC , 1999

Sposito, G. The chemistry of soils. New York: Oxford University Press; 1989.

Tiecher T, Pias OHC, Bayer C, Martins AP, Denardin LGO, Anghinoni I. Crop response to gypsum application to subtropical soils under no-till in Brazil: a systematic review. Revista Brasileira de Ciência do Solo, Viçosa, Brazil, v.4, 2018 :e0170025. https://doi. org/10.1590/18069657rbcs20170025

Vale AR do; Calderaro RAP; Fagundes FN. A CAFEICULTURA EM MINAS GERAIS: estudo comparativo entre as regiões Triângulo Mineiro/ Alto Paranaíba e Sul/Sudoeste. Revista de geografia agrária. Edição especial do XXI ENGA-2012, p. 1-23, jun., 2014.

WOLT, J.D. Obtaining soil solution: laboratory methods. In: Soil solution chemistry: applications to environmental science and agriculture. 1 ed. New York, John Wiley, 1994. 345p.

Zambrosi, F.C.B.; Alleoni, L.R.F.; Caires, E.F. Aplicação de gesso agrícola e especiação iônica da solução de um Latossolo sob sistema plantio direto. Ciência Rural, v. 37, p. 110-117, 2007. doi: 10.1590/S010384782007000100018 .

Zandoná R. R.; Beutler A. N.; Burg, G. M.; Barreto, C. F.; Schmidt, M. R. Gesso e calcário aumentam a produtividade e amenizam o efeito do déficit hídrico em milho e soja. Pesquisa Agropecuária Tropical, v. 45, n. 2, p. 128-137, 2015.

Zoca, S.M.; Penn, C. An important tool with no instruction manual: a review of gypsum use in agriculture. Advances in Agronomy, v.144, p.1-44, 2017. 